This item was submitted to Loughborough's Research Repository by the author.

Items in Figshare are protected by copyright, with all rights reserved, unless otherwise indicated.

\title{
Emerging advanced oxidation processes for the elimination of micro- pollutants
}

PLEASE CITE THE PUBLISHED VERSION

http://dx.doi.org/10.1016/j.cej.2017.03.053

\section{PUBLISHER}

(C) Elsevier

VERSION

AM (Accepted Manuscript)

\section{PUBLISHER STATEMENT}

This work is made available according to the conditions of the Creative Commons Attribution-NonCommercialNoDerivatives 4.0 International (CC BY-NC-ND 4.0) licence. Full details of this licence are available at: https://creativecommons.org/licenses/by-nc-nd/4.0/

\section{LICENCE}

CC BY-NC-ND 4.0

\section{REPOSITORY RECORD}

Mantzavinos, Dionissios, loannis Poulios, Santiago Esplugas, Taicheng An, Gianluca Puma, and Dionysios D. Dionysiou. 2017. "Emerging Advanced Oxidation Processes for the Elimination of Micro-pollutants". figshare. https://hdl.handle.net/2134/25615. 


\section{Emerging Advanced Oxidation Processes for the Elimination of Micro-Pollutants}

Following the commitment of the Chemical Engineering Journal to the publication of high quality research articles on important and contemporary topics in the field of environmental monitoring and protection technologies, this special issue contains a selection of 32 papers dealing with the application of advanced oxidation processes (AOPs) for the removal of pollutants and pathogens from environmentally relevant samples. AOPs constitute a family of processes that rely on the involvement of reactive oxygen species, mainly but not exclusively hydroxyl radicals, that can destroy a wide array of organic and inorganic pollutants, as well as inactivate pathogens in several matrices including surface, drinking and ground water, municipal and industrial wastewaters, soil and air. This special issue is a collection of papers reporting timely fundamental and applied research on the environmental applications of AOPs.

The articles included in this special issue entitled "Emerging Advanced Oxidation Processes for the Elimination of Micro-Pollutants" covers, among others, topics related to the degradation of pharmaceuticals, endocrine disruptors, toxins, agrochemicals and surface active substances in aqueous media using methods such as heterogeneous photocatalysis, catalytic ozonation, wet peroxide oxidation, electrochemical oxidation, Fenton and Fenton-like reactions, reactions based on the sulfate radical, as well as various hybrid combinations of the above. Emphasis is given on the synthesis, characterization and testing of new catalytic and photocatalytic materials, as well as on mechanistic and kinetic studies to gain insights into the investigated processes. Other topics include polluted soil remediation, $\mathrm{NO}_{\mathrm{x}}$ and VOCs removal, disinfection, process modelling and intensification, as well as photoelectrocatalytic water splitting and $\mathrm{CO}_{2}$ reduction.

We wish to thank the Editors of Chemical Engineering Journal, and in particular Professor D.D. Dionysiou, for giving us the opportunity to compile this special issue. Special thanks are due to the editorial assistants for their invaluable assistance in preparing this special issue. We are also indebted to all the authors and reviewers, who helped making this issue an important reference material.

\section{Dionissios Mantzavinos}

University of Patras, Department of Chemical Engineering, University Campus, Caratheodory 1, GR-26504 Patras, Greece, mantzavinos@chemeng.upatras.gr 
Ioannis Poulios

Aristotle University of Thessaloniki, Department of Chemistry, Laboratory of Physical Chemistry, GR-54124 Thessaloniki, Greece, poulios@chem.auth.gr

\section{Santiago Esplugas}

University of Barcelona, Department of Chemical Engineering, C/Martí i Franquès 1, 08028 Barcelona, Spain, santi.esplugas@ub.edu

\section{Taicheng An}

Guangzhou Institute of Geochemistry, Chinese Academy of Sciences, State Key Laboratory of Organic Geochemistry, Tianhe District, Guangzhou, GD 510640, China, antc99@gig.ac.cn

\section{Gianluca Li Puma}

Environmental Nanocatalysis \& Photoreaction Engineering, Department of Chemical Engineering, Loughborough University, Loughborough LE11 3TU, United Kingdom, g.lipuma@lboro.ac.uk

Dionysios D. Dionysiou

Environmental Engineering and Science Program, Department of Biomedical, Chemical and Environmental Engineering (DBCEE), 705 Engineering Research Center, University of Cincinnati Cincinnati, OH 45221-0012, USA, dionysios.d.dionysiou@uc.edu 